\title{
Penerapan Model Missouri Mathematics Project Untuk Meningkatkan Hasil Belajar
}

\author{
Laely Nurul Aini*1, Sri Muryaningsih', Dedy Irawan ${ }^{3}$ \\ ${ }^{1,2,3}$ Program Studi Pendidikan Guru Sekolah Dasar, Fakultas Keguruan dan Ilmu Pendidikan, \\ Universitas Muhammadiyah Purwokerto, Indonesia \\ e-mail:*1laelynurulaini@gmail.com ${ }^{2}$ srimuryaningsihump@gmail.com,${ }^{3}$ dedy.pgsd@gmail.com
}

\begin{abstract}
ABSTRAK
Penelitian ini bertujuan untuk meningkatkan hasil belajar matematika. Penelitian ini merupakan penelitian tindakan kelas yang dilaksanakan dalam 2 kali pertemuan, dengan menggunakan model Missouri Mathematics Project. Berdasarkan hasil penelitian, hasil belajar pengetahuan pada pertemuan I mendapatkan nilai 71,8 dengan kategori baik, dan ketuntasan 75\%. Pada pertemuan II mendapatkan presentase 80,5 dengan kategori baik, dan ketuntasan belajar 80\%. Hasil belajar sikap percaya diri pada pertemuan I mendaptkan nilai 2,5 dengan kategori cukup, dan pada pertemuan II mendaptkan presentase 3,25 dengan kategori baik. Hasil belajar keterampilan menyelesaikan soal matematika pada pertemuan I mendapatkan nilai 2,5 dengan kategori cukup dan pada pertemuan II mendapatkan presentase 3,08 dengan kategori baik. Hasil belajar pada aspek pengetahuan, sikap percaya diri, dan keterampilan menyelesaikan soal matematika telah mencapai indikator keberhasilan. Dapat disimpulkan bahwa model Missouri Mathematics Project dapat meningkatkan hasil belajar matematika peserta didik kelas IV SDN 1 Banjarsari Wetan.
\end{abstract}

Kata Kunci: Hasil Belajar, Missouri Mathematics Project, Matematika

\begin{abstract}
This research is aimed to increase the output of math learning. This research is conducted in form of class action research which is held in 2 meetings using Missouri Mathematics Project model. Based on the result, the learning outcome in meeting I gets the percentage of 71,8 with category of Good, and mastery learning of $75 \%$. In meeting II, gets the percentage of 80,5 with category of Good, mastery learning of $80 \%$. The outcome of confidence learning in meeting I gets the percentage of 2,5 with category of Enough, meanwhile in meeting II gets the percentage of 3,25 with the category of Good. The outcome of solving math skills in meeting I gets the percentage of 2,5 with category of Enough, meanwhile meeting II gets the percentage of 3,08 with category of Good. The learning outcomes in aspect of science, confidence, and solving math skill have reached the indicator of success. It can be concluded that Missouri Mathematics Projects model is able to increase the math learning outcome of grade IV students of SDN 1 Banjarsari Wetan.
\end{abstract}

Keywords: Learning Outcome, Missouri Mathematics Project, Math

\section{PENDAHULUAN}

Kurikulum 2013 merupakan suatu wujud pembaharuan yang dilakukan oleh pemerintah untuk menciptakan generasi muda yang berkualitas. Penerapan Kurikulum 2013 di Sekolah Dasar (SD) masih belum sepenuhnya diterapkan di seluruh kelas, karena masih ada keterbatasan fasilitas yang dimiliki oleh sekolah, sehingga dapat menimbulkan suatu permasalahan dalam penerapan Kurikulum 2013. Penerapan pembelajaran pada Kurikulum 2013 sudah menggunakan tematik terpadu sehingga pembelajaran dilakukan pertema, tetapi di kelas tinggi muatan Matematika dan Pendidikan Jasmani Olahraga dan Kesehatan (PJOK) terpisah.

Pemisahan pada mata pelajaran matematika bertujuan untuk memberikan pemahaman materi, sehingga memudahkan peserta didik untuk menerima dan memahami konsep matematika. Pemahaman konsep matematika bagi peserta didik untuk menunjang dan mengembangkan ilmuilmu lainnya, serta berguna dan bermanfaat dalam kehidupan sehari-hari [1]. Matematika juga berfungsi untuk menumbuhkan pengetahuan, sikap dan keterampilan peserta didik. 
Kegiatan pembelajaran yang dilakukan guru pada mata pelajaran matematika masih menggunakan metode ceramah. Metode ceramah sendiri merupakan metode pembelajaran yang mengharuskan peserta didik untuk memperhatikan guru dalam menyampaikan materi pembelajaran. Sehingga peserta didik kurang aktif dan kurang bisa menggali kemampuan yang dimiliki oleh setiap peserta didik. Kemampuan yang harus dimiliki oleh peserta didik untuk menunjang hasil belajar yaitu: peserta didik harus memiliki kemampuan dalam hal menghitung dan kemampuan dalam hal memahami materi yang diberikan oleh guru. Hal ini juga dialami di SD Negeri 1 Banjarsari Wetan.

Pada kegiatan belajar mengajar guru belum menggunakan media pembelajaran. Terutama pada mata pelajaran matematika, guru belum menggunakan media pembelajaran matematika. Kondisi tersebut akan mempengaruhi nilai yang didapatkan oleh peserta didik. Hal ini dapat dilihat dari hasil belajar aspek pengetahuan peserta didik dari nilai PTS pada tahun ajaran 2018/2019 peserta didik kelas IV bahwa lebih dari $80 \%$ peserta didik tidak mencapai nilai KKM yaitu 61 pada hasil nilai Penilaian Tengah Semester (PTS). Hal ini dilihat dari 20 jumlah peserta didik dan hanya 2 peserta didik yang mencapai KKM sedangkan 18 peserta didik lainnya masih di bawah KKM. Sehingga diperoleh presentase kelulusan belajar hanya berjumlah $10 \%$.

Berdasarkan dari hasil observasi dan wawancara yang dilakukan peneliti dengan guru kelas IV selama 3 kali dengan jumlah waktu 6 jam, diperoleh hasil bahwa sikap peserta didik terkait dengan percaya diri juga masih rendah. Indikator percaya diri yaitu berani menyatakan pendapat, berani bertanya dan menjawab pertanyaan, pantang menyerah, mengutamakan usaha sendiri daripada bantuan dan berpenampilan tenang [2]. Rendahnya percaya diri peserta didik dapat dilihat dari sikap peserta didik selama kegiatan belajar berlangsung yaitu mengenai bertanya dan menyatakan pendapat. Di samping itu keterampilan peserta didik dalam menyelesaikan soalsoal matematika juga masih kurang, dilihat dari cara peserta didik menerapkan konsep matematika dalam menyelesaikan soal-soal yang masih banyak ketidak sesuaian.

Hasil belajar berupa kemampuan yang dimiliki peserta didik setelah menerima pengalaman belajar [3]. Hasil belajar matematika yang rendah menjadi suatu permasalahan yang harus diselesaikan dengan melakukan perbaikan dari proses pembelajaran sebelumnya. Oleh sebab itu, untuk memperbaiki pembelajaran dan meningkatkan pencapaian hasil pembelajaran, peneliti perlu mengkaji ulang dengan melakukan Penelitian Tindakan Kelas (PTK) menggunakan model pembelajaran Missouri mathematics project (MMP).

Model pembelajaran Missouri Mathematics Project (MMP) sesuai digunakan karena melalui model pembelajaran ini mendukung peserta didik memperoleh lebih banyak penjelasan dan dapat mengembangkan keterampilan mengerjakan berbagai bentuk soal. Proses pengaplikasian materi dengan menggunakan model pembelajaran Missouri Mathematics Project dapat membuat pembelajaran menjadi lebih efektif, karena memperoleh banyak materi dari berbagai pengembangan materi dalam soal-soal latihan yang disajikan kepada peserta didik [4]. Karakteristik model pembelajaran MMP adalah berbasis proyek. Hal ini terlihat dari penyajian suatu lembar tugas proyek matematika, yang berisi soal-soal latihan penerapan materi matematika yang harus diselesaikan oleh peserta didik [5].

Penelitian ini akan mengupayakan meningkatkan pemahaman konsep pada peserta didik tentang materi matematika yang dilakukan dalam 1 siklus 2 kali pertemuan, pada setiap pertemuan. Pembelajaran yang menyenangkan dapat dilakukan dengan menggunakan model dan media pembelajaran yang bervariasi. Sehingga peserta didik tidak merasa bosan dalam mengikuti pembelajaran [6].

\section{METODOLOGI PENELITIAN}

Adapun bentuk penelitian yang digunakan yaitu Penelitian Tindakan Kelas yang dilaksanakan di kelas IV SD Negeri 1 Banjarsari Wetan tahun ajaran 2019/2020. Subjek yang diambil pada penelitian ini adalah peserta didik kelas IV SD Negeri 1 Banjarsari Wetan, dengan jumlah 20 peserta didik, terdiri dari 8 peserta didik laki-laki dan 12 peserta didik perempuan. 
Jurnal Ilmiah KONTEKSTUAL, Volume.2, No.01, Agustus 2020, pp. xx-xx

Desain yang digunakan dalam penelitian ini adalah model siklus dari Kemmis dan Pada model ini dapat diketahui bahwa didalam satu siklus atau putaran terdiri dari empat komponen yaitu, planning, acting, observing dan reflecting [7]. Teknik pengumpulan data pada penelitian ini menggunakan teknik tes yang meliputi: tes tertulis dan tes lisan, juga menggunakan teknik non tes meliputi: pengamatan, wawancara dan dokumentasi.

\section{HASIL DAN PEMBAHASAN}

\section{Hasil Penelitian}

Setelah melakukan penelitian, peneliti menemukan adanya peningkatan dengan menggunakan model Missouri Mathematics Project yang ditunjukkan dengan adanya peningkatan pada pengetahuan, sikap percaya diri dan keterampilan dalam menyelesaikan soal matematika. Peningkatan tersebut diperoleh dari aspek pengetahuan pada pertemuan I ke pertemuan II. Hasil tersebut dapat diukur dari pengetahuan peserta didik mengenai materi yang disampaikan dan diterapkan dalam bentuk latihan soal evaluasi. Untuk mengetahui lebih jelas mengenai peningkatan yang terjadi pada aspek pengetahuan, disajikan tabel 1 hasil rekapitulasi pengetahuan peserta didik sebagai berikut:

Tabel 1 Rekapitulasi Pengetahuan Peserta Didik

\begin{tabular}{lcc}
\hline \multicolumn{1}{c}{ Keterangan } & Pertemuan I & Pertemuan II \\
\hline Jumlah peserta didik & 20 & 20 \\
\hline KKM & 61 & 61 \\
\hline Nilai Tertinggi & 90 & 95 \\
\hline Nilai Terendah & 55 & 50 \\
\hline Rata-Rata & 71,8 & 80,5 \\
\hline Presentase & $75 \%$ & $80 \%$ \\
\hline Kategori & Baik & Baik \\
\hline
\end{tabular}

Berdasarkan data tabel 1 menunjukkan adanya peningkatan pengetahuan dari pertemuan I ke pertemuan II dengan menunjukan kategori baik. Hasil tersebut didapatkan setelah melakukan penelitian, peserta didik menunjukkan keaktifan dan pemahaman peserta didik meningkat. Sehingga nilai yang diperoleh peserta didik dalam mengerjakan lembar evaluasi sudah mencapai di atas nilai KKM sebesar 61.

Hasil peningkatan aspek sikap disajikan dalam tabel 2, dari tabel tersebut menunjukkan adanya peningkatan penilaian pada pertemuan I ke pertemuan II dengan pembelajaran missouri mathematics project. Peningkatan tersebut dilihat pada pertemuan I diperoleh kategori cukup dan pada pertemuan II mendapat kategori baik. Penilaian sikap percaya diri disajikan pada tabel 2 sebagai berikut:

Tabel 2 Hasil Sikap Percaya Diri

\begin{tabular}{lcc}
\hline \multicolumn{1}{c}{ Indikator penilaian } & Pertemuan I & Pertemuan II \\
\hline Mmematuhi prosedur kegiatan pembelajaran & 45 & 70 \\
\hline Mengerjakan tugas matematika yang diberikan guru & 80 & 80 \\
\hline Mengerjakan tugas dengan jujur tidak mencontek & 55 & 65 \\
\hline Menjawab pertanyaan yang disampaikan guru dengan sopan & 25 & 50 \\
\hline Aktif kegiatan berdiskusi dalam kelompok & 45 & 60 \\
\hline Jumlah & 250 & 325 \\
\hline Rata-rata & 50 & 65 \\
\hline Rata-rata tiap peserta didik & 2,5 & 3,25 \\
\hline Kriteria & Cukup & Baik \\
\hline
\end{tabular}

Berdasarkan dari data tabel 2 menunjukkan adanya peningkatan nilai dari pertemuan I ke pertemuan II dengan menerapkan missouri mathematics project. Perolehan penilaian aspek sikap percaya diri, diperoleh setelah peserta didik mendapatkan pembelajaran dengan menerapkan 
Jurnal Ilmiah KONTEKSTUAL, Volume.2, No.01, Agustus 2020, pp. xx-xx

model missouri mathematics project. Pertemuan I mendapatkan presentase 2,5 kategori cukup. Mengalami peningkatan pada pertemuan II mendapatkan presentase 3,25 kategori baik. Hasil ini didapatkan dari perolehan nilai peserta didik pada saat mengerjakan lembar soal evaluasi. Dari hasil tersebut peserta didik sudah aktif dalam kegiatan diskusi dan bekerjasama dengan kelompok pada saat menjawab soal.

Hasil peningkatan pada aspek keterampilan disajikan dalam tabel 3, dari tabel tersebut menunjukkan adanya peningkatan penilaian pada pertemuan I ke pertemuan II dengan pembelajaran missouri mathematics project. Peningkatan tersebut dilihat pada pertemuan I diperoleh kategori cukup dan pada pertemuan II mendapat kategori baik. Penilaian keterampilan menyelesaikan soal matematika disajikan pada tabel 3 sebagai berikut:

Tabel 3 Hasil Keterampilan Menyelesaikan Soal Matematika

\begin{tabular}{lcc}
\hline \multicolumn{1}{c}{ Indikator penilaian } & Pertemuan I & Pertemuan II \\
\hline Mengamati proses pembelajaran dengan baik dan benar & 75 & 80 \\
\hline Aktif pada kegiatan tanya jawab & 30 & 50 \\
\hline Menyelesaikan soal latihan dengan baik & 75 & 85 \\
\hline Membuat kesimpulan berdasarkan kegiatan pembelajaran & 40 & 45 \\
\hline Membuat rangkuman materi yang telah disampaikan & 35 & 50 \\
\hline Mampu mengumpulkan data dan membaca data & 45 & 60 \\
\hline Jumlah & 300 & 370 \\
\hline Rata-rata & 50 & 61,6 \\
\hline Rata-rata tiap peserta didik & 2,5 & 3,08 \\
\hline Kriteria & Cukup & Baik \\
\hline
\end{tabular}

Berdasarkan dari data tabel 3 menunjukkan adanya peningkatan nilai dari pertemuan I ke pertemuan II dengan menggunakan model pembelajaran missouri mathematics project. Perolehan penilaian aspek keterampilan menyelesaikan soal matematika, diperoleh setelah peserta didik mendapat pembelajaran dengan menggunakan model pembelajaran missouri mathematics project, pada pertemuan I mendapatkan presentase 2,5 kategori cukup. Mengalami peningkatan pada pertemuan II mendapatkan prsentase 3,08 kategori baik. Hal tersebut dibuktikan dengan peserta didik telah terampil dalam mengerjakan latihan soal matematika.

\section{Pembahasan}

\section{Penilaian aspek pengetahuan}

Penilaian pengetahuan menggunakan lembar tes evaluasi dan LKPD, dalam tes tersebut peserta didik bisa menggali kemampuan yang dimiliki dari masing-masing peserta didik agar nilai yang diperoleh baik. Aspek pengetahuan yang meliputi 6 aspek yakni mengetahui, memahami, menerapkan, menganalsisi, mengevaluasi, dan mencipta [8]. Hasil penelitian seperti tersaji pada Gambar 1 menunjukkan adanya peningkatan pengetahuan peserta didik melalui model pembelajaran Missouri Mathematics Project.

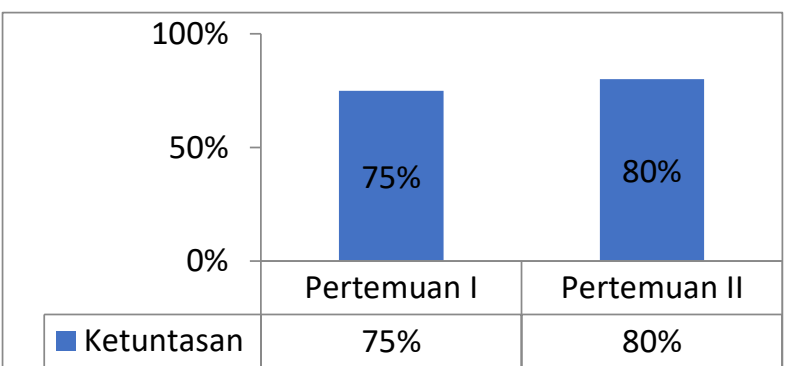

Gambar 1 Histogram penilaian pengetahuan peserta didik

Berdasarkan gambar histogram 1 tersebut, memberikan gambaran bahwa adanya peningkatan penilaian pengetahuan. Hasil peningkatan tersebut didapat pada pertemuan I dan pada pertemuan II. Dari hasil yang didapatkan pada pertemuan awal setelah menggunakan model pembelajaran mendapatkan ketuntasan $75 \%$, pada pertemuan berikutnya mendapat 
Jurnal Ilmiah KONTEKSTUAL, Volume.2, No.01, Agustus 2020, pp. xx-Xx

ketuntasan $80 \%$ kategori baik. Hasil yang didapatkan peserta didik telah mencapai nilai KKM yaitu sebesar 61.

Penilaian pengetahuan meningkat diperoleh setelah guru menggunakan model pembelajaran ini. Hal ini karena dengan guru menggunakan model pembelajaran peserta diidk menjadi kritis dalam menerima materi dan aktif dalam mengerjakan latihan soal. Hasil tersebut diperkuat bahwa model pembelajaran missouri mathematics project itu sendiri adalah model pembelajaran matematika melalui penugasan berupa soal-soal latihan yang diselesaikan baik secara individu maupun kelompok untuk dapat mengaplikasikan pengetahuan yang didapat peserta didik [9]. Sehingga peserta didik dapat meningkatkan pengetahuan melalui latihanlatihan soal yang diberikan.

\section{Penilaian Sikap Percaya Diri}

Penilaian sikap percaya diri didapatkan dari hasil penilaian lembar sikap peserta didik pada saat mengikuti pembelajaran. Dari hasil sikap tersebut dibagi menjadi beberapa kategori, yaitu: a) Penerimaan, berkaitan dengan reaksi menerima rangsangan pada peserta didik, b) Menanggapi, berkaitan dengan adanya peran aktif peserta didik dalam suatu kejadian, c) Penilaian, berkaitan dengan memberi nilai, penghargaan dan sebuah kepercayaan kepada suatu gejala, d) Mengelola, berkaitan dengan kegiatan mengkonsepkan nilai-nilai menjadi sebuah sistem nilai, dan e) Karakterisasi, berkaiatan dengan keterpaduan seluruh karakter peserta didik yang berpengaruh pada kepribadian setiap orang [10].

Peningkatan ini dapat dilihat pada gambar 2, dari gambar penilaian sikap di bawah ini menunjukkan adanya peningkatan pada pertemuan I ke pertemuan II dengan menggunakan missouri mathematics project. Peningkatan penilaian sikap percaya diri disajikan dalam gambar histogram sebagai berikut:

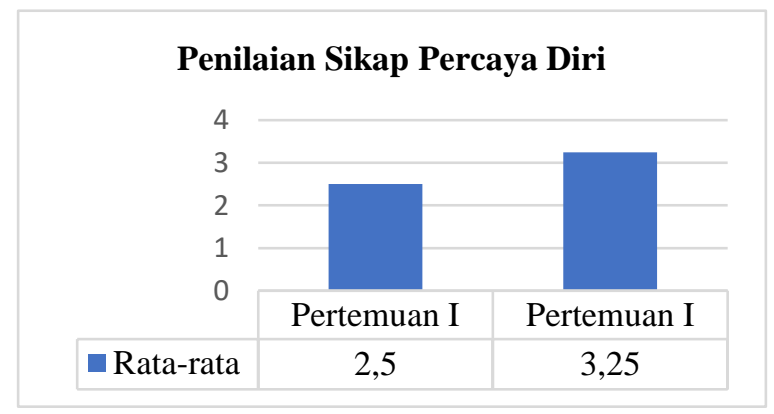

Gambar 2 Histogram Penilaian Aspek Sikap

Berdasarkan gambar histogram 2 tersebut, memberikan gambaran bahwa adanya peningkatan penilaian sikap percaya diri. Peningkatan penilaian sikap percaya diri diperoleh setelah guru menggunakan model pembelajaran. Perolehan penilaian pada pertemuan I mendapatkan presentase 2,5 kategori cukup, mengalami peningkatan pada pertemuan II mendapatkan presentase 3,25 kategori baik. Hal tersebut diperkuat bahwa menerapkan model pembelajaran missouri mathematics project dapat memberikan kesempatan bagi peserta didik agar lebih aktif dalam mengkomunikasikan ide matematika mereka [11].

\section{Penilaian Keterampilan Menyelesaikan Soal Matematika}

Hasil penilaian keterampilan menyelesaikan soal matematika diukur dengan lembar observasi yang sesuai dengan indikator aspek keterampilan. Indikator aspek keterampilan dibagi itu sendiri dibagi menjadi 6 tingkatan, yaitu: mengamati (peserta didik mengamati proses pembelajaran dengan baik), menanya (peserta didik aktif pada kegiatan tanya jawab), mencoba (peserta didik menyelesaikan soal latihan dengan baik), menalar (peserta didik membuat kesimpulan berdasarkan kegiatan pembelajaran), menyaji (peserta didik membuat rangkuman materi yang telah disampaikan) dan mencipta (peserta didik mampu mengumpulkan data dan membaca data) [12]. 
Peningkatan ini dapat dilihat pada gambar 3, dari gambar penilaian keterampilan menyelesaikan soal di bawah ini menunjukkan adanya peningkatan pada pertemuan I ke pertemuan II dengan menggunakan missouri mathematics project. Peningkatan penilaian keterampilan menyelesaikan soal matematika disajikan dalam gambar histogram sebagai berikut:

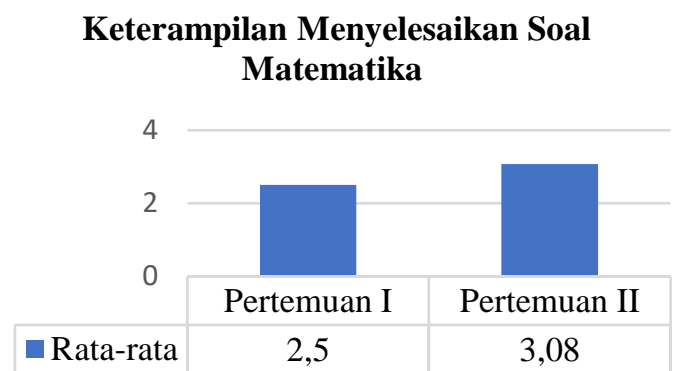

Gambar 3 Histogram Penilaian Keterampilan Menyelesaikan Soal Matematika

Berdasarkan gambar histogram 3 tersebut, memberikan gambaran bahwa adanya peningkatan penilaian keterampilan menyelesaikan soal. Penilaian keterampilan menyelesaikan soal matematika diperoleh setelah guru menggunakan model pembelajaran. Pada pertemuan I mendapatkan presentase 2,5 kategori cukup. Mengalami peningkatan pada pertemuan berikutnya mendapatkan presentase 3,08 kategori baik. Peningkatan tersebut dikarenakan setelah menggunakan model pembelajaran peserta didik menjadi terampil pada saat mengerjakan lembar kerja peserta didik dan lembar evaluasi, sehingga peserta didik mampu menyelesaikan soal. Proses pembelajaran dengan menggunakan model pembelajaran ini menjadikan peserta didik lebih aktif dalam mengerjakan latihan soal. Model pembelajaran missouri mathematics project (MMP) akan memberikan lebih banyak tugas berupa soal untuk diselesaikan dibawah bimbingan dan arahan guru, sehingga tidak terjadi miskonsepsi dan peserta didik akan lebih terampil dalam berbagai macam jenis soal [13].

\section{SIMPULAN}

Adapun dari hasil penelitian yang telah dilakukan, untuk Meningkatkan Hasil Belajar Matematika dengan Menggunakan Model Pembelajaran Missouri Mathematics Project (MMP) Kelas IV Peserta Didik SD Negeri 1 Banjarsari Wetan. Dapat ditarik kesimpulan: (1) Penilaian aspek pengetahuan pada pada awal melakukan penelitian dengan mendapatkan presentase 71,8 nilai ketuntasan $75 \%$. Perolehan peningkatan terjadi pertemuan selanjutnya dengan presentase 80,5 nilai ketuntasan $80 \%$. Peningkatan tersebut dibuktikan dari hasil penelitian bahwa peserta didik sudah aktif dan lebih mudah dalam memahami konsep matematika melalui latihan soal. Nilai tersebut telah mencapai tujuan yang diinginkan dengan mendapat presentase nilai minimal $80 \%$ dari nilai KKM 61. Penilaian aspek sikap pada awal melakukan penelitian mendapatkan presentase 2,5 kategori cukup. Perolehan peningkatan hasil pada aspek sikap dilihat dari adanya peningakatan pada pertemuan berikutnya dengan presentase 3,25 kategori baik. Peningkatan tersebut terbukti dari hasil penelitian bahwa siswa sudah aktif berdiskusi dan menjawab pertanyaan. (3) Penilaian aspek keterampilan menyelesaikan soal matematika pada awal melakukan penelitian dengan mendapatkan presentase 2,5 kategori cukup. Peningkatan terjadi pada pertemuan berikutnya didapat sebesar 3,08 kategori baik. Peningkatan tersebut dibuktikan dari hasil penelitian di kelas IV sudah terampil pada saat menjawab lembar kerja peserta didik dan lembar evaluasi. 


\section{REFERENCES}

[1] S. Muryaningsih and S. Irianto, "Math Games Domino Effect on the Results of the Learning Math Fractions In Class IV SD Negeri 1 Kalikabong, Jurnal Dinamika Pendidikan Dasar. Vol. 7, no. 2, pp. 31-42, 2015, [Online]. Available: https://www.bing.com/search?q=jurnalnasional.ump.ac.id/index.php/Dinamika/article/v iew/930/869\%C2\%A0\&form=IPRV10

[2] Mulyasa, "Pengembangan dan Implementasi Kurikulum 2013”, 2014, PT Remaja Rosdakarya, Bandung.

[3] A. Bate'e, "Penerapan Model Pembelajaran Kooperatif Tipe Group Investigation Untuk Meningkatkan Motivasi dan Hasil Belajar Matematika SD Negeri 4 Idanogawo, Jurnal Bina Gogik, vol. 2, no. 1, pp. 25-31, 2015, [Online]. Available: https://ejournal.stkipbbm.ac.id/index.php/pgsd/arrticle/view/86

[4] Isrok'atun and Rosmala, A, "Model-Model Pembelajaran Matematika", 2018, Bumi Aksara, Jakarta.

[5] A. S. Misi, "Improving of Motivation and Learning Achievement of Mathematics by Using Missouri Mathematics Projects (MMP) of Learning Models and High Order Thinking (HOT) on Limit Trigonometric Topic," Prosiding SS9 \&URICES, no 3, pp. 441-453, 2019, [Online]. Available: https://ices.prosiding.unri.ac.id/index.php/ICES/issue/view/793/showToc

$[6,11]$ W. B. Sulfemi and Z. Desmiati, "Model Pembelajaran Missouri Mathematics Project Berbantu Media Relief Experience Dalam Meningkatkan Hasil Belajar Siswa", Jurnal Pendas Mahakam, vol. 3, no. 3, pp. 232-245, 2018, [Online]. Available: https://jurnal.fkip-uwgm.ac.id/index.php/pendasmahakam/article/view/269

[7] Kemmis, S., R. McTaggart, dan R. Nixon, "The Action Research Planner", 2014, Springer, Singapore.

[8,9] Ariyana, "Buku Pegangan Pembelajaran Berorientasi pada Keterampilan Berpikir Tingkat Tinggi", 2018, Direktorat Jenderal Guru dan Tenaga Kependidikan Kementerian Pendidikan dan Kebudayaan.

[10] E. M. Sagarih, "Upaya Meningkatkan Hasil Belajar Matematika Siswa Dalam Penerapan Model Pembelajaran Missouri Mathematics Project (MMP)", Open Jurnal System (OJS), vol. 6, no. 11, pp. 546-551, 2017, [Online]. Available: http://jurnal.una.ac.id/index.php/id/article/view/698/0

[12] I. Swarsaya, Kartono and Watutup, "Mathematics Communication Skill Analysis Seen from Emotional Quotient on Fast Feedback in Missouri Mathematics Project Learning", UJMER, vol. 10, no. 1, pp. 48-54, 2020, [Online]. Available: https://journal.unnes.ac.id/sju/index.php/ujmer/article/view/34613

[13] Kemendikbud, "Peraturan Menteri Pendidikan Dan Kebudayaan Republik Indonesia Nomor 22 Tahun 2016 tentang Standar Proses Pendidikan Dasar dan Menengah", 2016, Kemendikbud, Jakarta. 